УДК 338.1 : 339.3

Сокуренко С. B.,

solomiya.sh@gmail.com,ORCID ID: 0000-0003-1459-5562,

аспірант, Львівський торговельно-економічний університет, м. Львів

\title{
ПРОГНОЗИ ЕКОНОМІЧНОЇ ДИНАМІКИ В УКРАЇНІ ПІД ЧАС ПАНДЕМІї COVID-19
}

\begin{abstract}
Анотація. За допомогою автоматичної процедури АRIMA зроблено прогноз показників валового внутрішнього продукту (ВВП), аграрного і промислового виробництва, а також роздрібного товарообігу на 2020 -2021 рр., щзо актуально з погляду оцінки перспектив відновлення економічного зростання в Україні. Враховано залежність зазначених макроекономічних показників від умов торгівлі, які визначено співвідношенням иін експорту (аграрна сировина, метали) й імпорту (сира нафта), а також обмінного курсу, пропозиції грошової маси $i$ тривалості карантинних заходів. Отримані результати передбачають спад ВВП на 11-12\% в 2020 р. та поступове відновлення економічного зростання до кінця 2021 р. Спад промислового виробництва очікується на рівні 18\%, щзо дещзо менше, ніж у 2008-2010 рр. Обсяги промислового виробництва стабілізуються вже на осінь 2020 р., але стрімкого відновлення вітчизняної промисловості не передбачається. Що гірше, зі середини 2021 р. відновлення української промисловості може істотно сповільнитися, подібно до того, як ие відбувалося в 2010 р. Обсяги аграрного виробництва дещзо знизяться до кінця 2020 р., але надалі матимемо незначне зростання изого показника. Найімовірніше, щчо післякризове відновлення аграрного сектора відбуватиметься за дещзо нижчою висхідною траєкторією, ніж у 2008-2009 рр. Багато залежить від обмінного курсу. Показано, щчо зниження обмінного курсу до 35 грн за долар матиме порівняно незначний рестрикційний вплив на зміни ВВП і роздрібного товарообігу, тоді як обсяги промислового виробництва будуть на 11\% нижчими до кіния 2021 р. порівняно з базовим сценарієм, щзо передбачає обмінний курс у межах 27-28 грн за долар. Кризові явища та обмінний курс не впливають на обсяги аграрного виробниитва. Проведене дослідження видається важливим для подальшого дослідження стабілізаційної функції обмінного курсу в Україні.
\end{abstract}

Ключові слова: Україна, валовий внутрішній продукт, аграрне і промислове виробництво, роздрібний товарообіг, Covid-19.

Sokurenko S. V., solomiya.sh@gmail.com, ORCID ID: 0000-0003-1459-5562, Postgraduate, Lviv University of Trade and Economics, Lviv

\section{FORECASTS OF MACROECONOMIC DEVELOPMENTS IN UKRAINE IN THE TIME OF COVID-19 PANDEMIC}

\begin{abstract}
With the use of automatic ARIMA procedure, forecasts for the 2000-2021 period of the gross domestic product (GDP), agricultural and industrial production, as well as of the retail trade turnover, are presented. Such a study is of interest for assessment of economic recovery in Ukraine. Causal links to the terms-of-trade, as defined by the ratio between export (agricultural raw materials and metals) and import (crude oil) commodity prices, as well as to exchange rate, money supply and the length of the quarantine period, are accounted for. Our results imply a decrease in the GDP level by 11-12\% in 2020, with a gradual recovery in output by the end of 2021. Decline in the industrial production is expected at 18\%, somewhat above a trough of the 2008-2010 period. Industrial production is supposed to stabilize by the fall of 2020; however, no fast recovery of Ukraine's industry is expected. Moreover, industrial growth could slow down since the middle of 2021, similar to developments earlier in 2010. Agricultural production will be lower by the end of 2020, with a weak recovery to follow. It is likely that post-crisis recovery of agriculture will be somewhat weaker as compared with the 2008-2009 period. Exchange rate behavior is important. It is demonstrated that a depreciation of the exchange rate up to 35 hryvnas per dollar would have relatively small contractionary impact upon the GDP and retail trade levels, while the level of industrial output is envisaged to be $11 \%$ lower by the end of 2021 in comparison with the basic scenario of exchange rate stability within the range between 27 and 28 hryvnas per dollar. Both crisis developments and exchange rate do not affect the agricultural production. Our study seems to be important for continuation of the research on the exchange rate shock-absorbing properties in Ukraine.
\end{abstract}

Key words: Ukraine, gross domestic product, agricultural and industrial production, retail trade turnover, Covid-19.

JEL Classification: C22, E27, E32, F31

DOI: https://doi.org/10.36477/2522-1205-2020-59-08 
Постановка проблеми. Для прогнозування траєкторії основних макроекономічних показників на 2020-2021 pр. певні труднощі створює врахування унікальності нинішніх кризових явищ, що мають переважно адміністративне походження і не супроводжувалося такими звичними у минулому явищами, як значний відплив капіталу чи стрімка девальвація гривні внаслідок надмірного дефіциту зовнішньої торгівлі або панічних настроїв на валютному ринку. 3 іншого боку, пандемія Covid-19 спостерігається на тлі входження економіки України в спадну фазу циклу ділової активності (зі середини 2019 р.), що передбачає підвищену глибину та більшу тривалість кризових явищ. Хоча у I кв. 2020 р. спад ВВП становив лише 1,5\%, надалі передбачається набагато більше зниження цього показника, а відновлення докризового рівня ВВП очікується не раніше, ніж у найближчі два-три роки. Втім, існуючі прогнози доволі суперечливі, що передбачає доцільність уточнення отриманих результатів за допомогою альтернативних статистичних методів.

Аналіз останніх досліджень і публікацій. Тривалість і амплітуда спаду виробництва оцінюється по-різному. На початку березня 2020 р. за допомогою моделі DSGE/CGE отримано, що в найгіршому сценарії ВВП промислових країн та декількох країн з нижчим доходом (Аргентина, Росія, Туреччина) до кінця 2020 р. знизиться на 6-10\%. Наприкінці квітня ц.р. експерти BIS передбачали спад світового ВВП на 4\%, причому з більшими втратами для промислових країн [14]. Експерти Світового банку на підставі власної моделі для глобальних пандемій отримали: ВВП країн, що розвиваються, знизиться на 2,5\%, а промислових країн на 1,8\%; якщо ж епідемія Covid-19 затягнеться в часі, амплітуда спаду виробництва зросте вдвічі [19]. Найбільше потерпатиме сфера послуг. Подібно для США: якщо в 2019 р. побоювання рецесії створювала промисловість, то на сьогодні - сфера послуг [15]. В іншому дослідженні отримано, що триваліша U-подібна траєкторія буде спостерігатися якраз у промисловості, тоді як у решті секторів відновлення матиме оперативний $\mathrm{V}$-подібний вигляд, хоча на сферу дозвілля чекає неприємна L-подібна траєкторія [19, pp. 81-85]. Більш оптимістичні розрахунки передбачають скорочення світового ВВП на 1,5\% [13, pp. 37-44].

Якими б не були експертні оцінки, реалії такі, що зроблені прогнози втрачають актуальність вже через декілька днів після публікації. Ще на початку травня офіційні прогнози Свропейської комісії передбачали спад ВВП європейських країн до кінця року на 7,4\% [16], проте вже до кінця місяця експерти Європейського Центрального Банку попередили, що спад виробництва може становити від 8 до $12 \%$ [17]. Загалом оцінки цьогорічного спаду ВВП для країн G20 перебувають у межах від 5-6\% (Японія, Бразилія, США) до 8-9\% (Італія, Іспанія). Економіка Китаю зросте лише на 1,2\%, що вп’ятеро нижче середнього значення за останні декілька років.
Український уряд прогнозує падіння реального ВВП на 4,2\%, що більш-менш співпадає 3 прогнозом НБУ [9]. Водночас МВФ передбачає більший спад ВВП - на 7,7\%. За результатами II кв. 2020 р. найбільші втрати очікуються у готельноресторанному бізнесі - на $82 \%$, промисловості $48 \%$, оптовій та роздрібній торгівлі - на $31 \%$. Водночас сільське господарство не зазнає втрат. Це контрастує 3 розрахунками на підставі системи національних рахунків, які передбачають найбільше падіння виробництва якраз в аграрному секторі - від 7,8 до 12,9\% [7]. Водночас промисловість скоротиться в межах 3,3-8,1\%, торгівля - 6,4-13,1\%, транспорт - 7,8-12,9\%; загалом падіння ВВП очікується у межах 5,9-11,2\%. Ще до початку карантину припускалося, що за оптимістичного сценарію падіння економіки України у 2020 р. складе 4-5\% ВВП, а за найгіршого сценарію - 9-10\% [5, с. 2026].

Попри відмінності у деталях, різноманітні прогнози співпадають у тому, що відновлення вітчизняної економіки триватиме не менше року. Подолання кризи сповільнять проблеми 3 обслуговуванням боргових зобов'язань (делеверідж) [2], певні фобії населення, а також зменшення надходжень від працюючих за кордоном [8].

Постановка завдання. Метою даної статті обрано опрацювання за допомогою статистичного методу ARIMA прогнозу українського ВВП та двох його компонент - аграрного і промислового виробництва, а також роздрібного товарообігу, на період до кінця $2021 \mathrm{p}$.

Викладення основного матеріалу дослідження. Можна погодитися, що нинішня економічна криза в Україні складатиметься $з$ двох етапів - карантинного й типового, який почнеться вже після завершення карантину [11]. На кожному з них очікуються падіння сукупного попиту та несприятливі шоки з боку сукупної пропозиції. Менший попит зумовлюють згадані вище перешкоди для спілкування людей, а також зменшення зайнятості та зростання песимістичних настроїв населення і бізнесу. Найімовірніше зменшиться попит на експорт, але одночасно стимулюючий вплив може мати прискорене зменшення імпорту. Так само сприятливим може бути пожвавлення внутрішнього туризму, але обидва чинники не варто перебільшувати. Навіть якщо сукупний попит відновиться, відновленню економічного зростання перешкоджатимуть такі чинники сукупної пропозиції, як дестабілізація ланцюгів постачання чи проблеми 3 отриманням кредитів або обслуговуванням попередніх боргових зобов'язань.

Для наших розрахунків умовно приймається, що амплітуда виключно кризового (тобто не пов'язаного 3 динамікою макроекономічних показників) спаду виробництва у I-II кв. 2020 р. вдвічі перевищує аналогічні події під час кризових явищ 2008-2009 і 2014-2015 pр. Таке припущення виглядає обгрунтованим передусім 3 погляду характеру запроваджених обмежень, які не спостерігалися в минулому (припинення транспортного сполучення 
і роботи більшості закладів сфери послуг, закриття кордонів тощо). У ІІІ кв. 2020 р. амплітуда кризових явищ зростає ще на третину (це природно 3 погляду труднощів “перезавантаження” економіки), а надалі поступово знижується. Песимістичний сценарій (\#1) передбачає, що екзогенний кризовий ефект зберігатиметься до весни 2021 р., а в оптимістичному (\#2) - до кінця 2020 р.

Методологія дослідження. Для прогнозування чотирьох показників - ВВП, промислового і аграрного виробництва, обсягів роздрібного товарообігу - використано автоматичну процедуру ARIMA(n,m), де n i m - порядок авторегресивного компонента і ковзної середньої відповідно. Це має переваги з погляду компактної структури статистичної моделі, що вигідно відрізняє від структурних регресійних моделей зі складнощами ідентифікації лагових залежностей. До того ж, моделі ARIMA передбачають врахування впливу незалежних змінних, що мають стосунок до змін залежної змінної. Як це передбачають дослідження для України, наприклад [6; 10, с. 273-295; 12], вагомий вплив на динаміку ВВП та його компонент мають обмінний курс, умови торгівлі та пропозиція грошової маси.

Вихідні припущення щодо пояснювальних (незалежних) змінних передбачають, що в 2020-2021 pp. обмінний курс перебуватиме у межах 27-28 грн за долар, умови торгівлі (співвідношення між цінами експорту та імпорту) поступово погіршуватимуться, а темп зростання грошової маси спочатку зростатиме упродовж 2020 р., але потім знизиться до передкризових значень. Обрані прогнозні траєкторії пояснювальних змінних на 2020-2021 рр. показано на рис. 1.

Передбачається, що обмінний курс перебуватиме на рівні 27 грн за долар до середини 2020 р., потім знизиться до 27,5 грн за долар, але з початку 2021 р. знову незначно зміцниться. Така траєкторія суперечить більшості експертних оцінок, але тим не менше видається більш реалістичною. Наприклад, в лютому 2020 р. Свропейська бізнесасоціація, з посиланням на інвестиційну компанію
Dragon Capital, у базовому сценарії передбачала, що на випадок збереження карантину до травня ц.р. глибина спаду ВВП складатиме 4\%, а обмінний курс знизиться до 29 грн за долар; якщо карантин триватиме до липня, спад ВВП мав становити 9\%, а обмінний курс гривні - 35 грн за долар [5, с. 20-26]. На наш погляд, такий прогноз обмінного курсу занадто песимістичний. Відсутність підстав для значної девальвації гривні пояснюється сприятливим сальдо поточного рахунку, поліпшенням цінових співвідношень у зовнішній торгівлі та відсутністю надлишкової пропозиції грошової маси (головним чином внаслідок зваженої монетарної політики в першій половині 2019 р.). Брак звичного для минулих років ажіотажного попиту на іноземну валюту може пояснюватися як досить оптимістичними макроекономічними показниками (окрім динаміки ВВП), так і серйозним зміцненням банківської системи в 2015-2017 pp. Зокрема, немає “втечі” капіталу через банківські канали, як це відбувалося в 2014-2015 рр. чи раніше в 2008-2009 рр., що здійснювало значний девальваційний тиск на гривню.

Умови торгівлі, які визначено співвідношенням світових цін на метали і аграрну сировину до цін на сиру нафту, поліпшилися за останній рік не менш ніж на 50\% (рис. 1б). Звичайно, така сприятлива ситуація навряд чи збережеться на майбутнє. Реалістичніше припустити, що поступове подорожчання енергоносіїв погіршить цінові співвідношення у зовнішній торгівлі приблизно на третину впродовж найближчих двох років.

Зростання грошової маси найімовірніше триватиме до кінця 2020 р. (цьому сприятиме низька інфляція першої половини цього року та сприятливий баланс попиту і пропозиції на валютному ринку), але надалі темп грошової емісії істотно знизиться. Зокрема, до цього спонукатиме прискорення інфляції та (не виключено) погіршення сальдо торговельного балансу напередодні зимового опалювального сезону 2020/2021 pр.

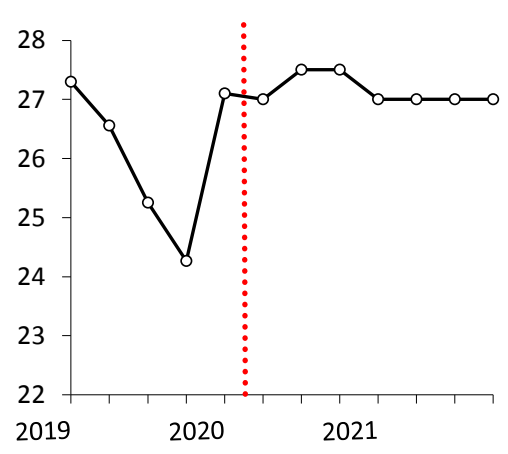

а) обмінний курс (грн/долар);

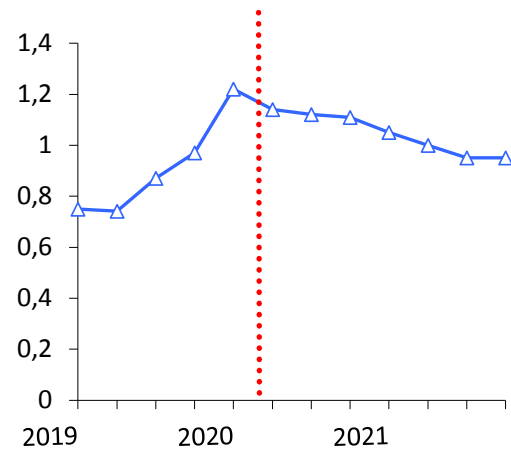

б) умови торгівлі;

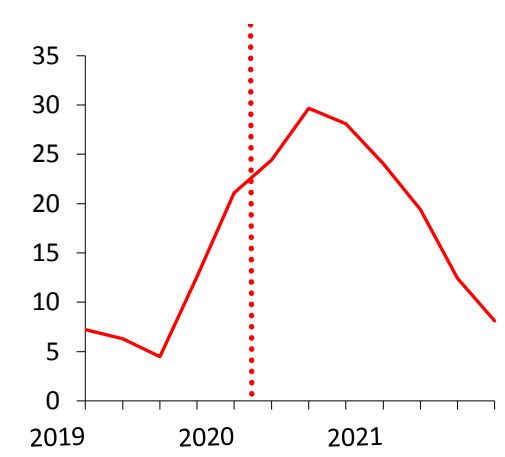

в) темп зростання грошової маси (\%);

Рис. 1. Фактичні та прогнозні значення пояснювальних змінних, 2019-2021 pp.

Джерело: розраховано за даними довідкового видання МВФ International Financial Statistics (www.imf.org) 
Отримані результати. Прогнози досліджуваних макроекономічних показників на період 2020-2021 рр. представлено на рис. 2. Для порівняння подано траєкторію цих показників під час фінансової кризи 2008-2009 рр. Все виглядає так, що динаміка ВВП у 2020-2021 рр. приблизно відповідатиме перебігу подій в 2009-2010 рр. Базовий сценарій передбачає, що в IV кв. 2020 р. спад ВВП становитиме $12,8 \%$, а зростання ВВП відновиться лише під кінець 2021 р. В оптимістичному сценарії кризове "дно" спостерігатиметься в III кв. 2020 р. (ВВП знизиться на 11,6\% проти відповідного періоду 2019 р.), а наприкінці 2021 р. зростання ВВП становитиме $4,4 \%$.

Спад обсягів промислового виробництва видається досить глибоким - до 18\% у II кв. 2020 р., хоча й дещо меншим, ніж у 2008-2010 pp. Одним із пояснень може бути вища база порівняння, адже упродовж 2007-2008 рр. в українській промисловості спостерігався локальний бум, тоді як в 2019 р. передкризова траєкторія вже була спадною. Промислове виробництво стабілізується вже до осені 2020 р., але стрімкого відновлення вітчизняної промисловості не передбачається. Що гірше, зі середини 2021 р. цей процес може істотно сповільнитися, подібно до того, як це відбувалося в 2010 р. Порівнюючи 3 початком 2019 р., до кінця наступного року втрати промислового виробництва становитимуть близько 15\%. Як зазначають окремі експерти, вплив Covid-19 на промисловість відбуватиметься головним чином через зменшення сукупного попиту [7]. Водночас не слід нехтувати чинниками сукупної пропозиції, де головним видається обмінний курс.

Обсяги аграрного виробництва дещо знизяться до кінця 2020 р., але надалі спостерігатиметься слабке зростання цього показника. Умовно можна вважати, що післякризове відновлення аграрного сектора відбуватиметься за дещо нижчою висхідною траєкторією, ніж у 2008-2009 рр. Також потрібно врахувати, що в 2007-2008 рр. спостерігалася передкризова стагнація сільського господарства, тоді як в 2019 р. відбувався досить відчутний підйом (за винятком IV кв. 2020 р.). У будь-якому разі не передбачається спаду обсягів аграрного виробництва, що, серед іншого, сприятиме поліпшенню сальдо торговельного балансу і стабілізації обмінного курсу гривні. Отримані результати істотно відрізняються від згаданого вище песимістичного прогнозу, що передбачає значне падіння обсягів аграрного виробництва внаслідок подвійного шоку від негативних економічних наслідків пандемiї Covid-19 та погіршення прогнозу врожаю через незвично суху погоду [7].

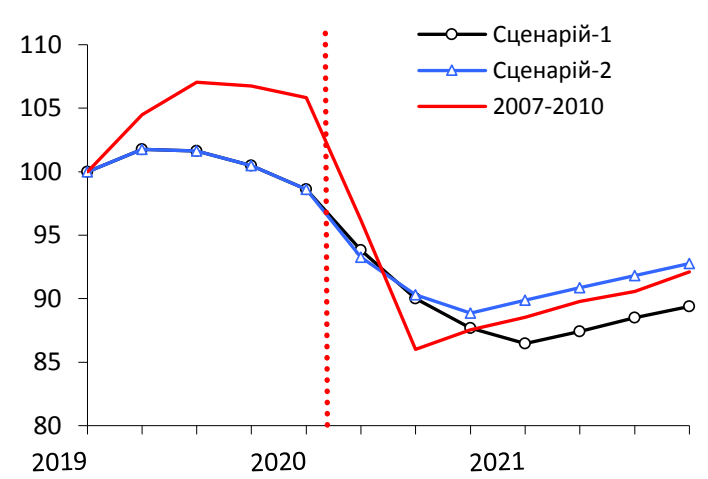

a) ВВП;

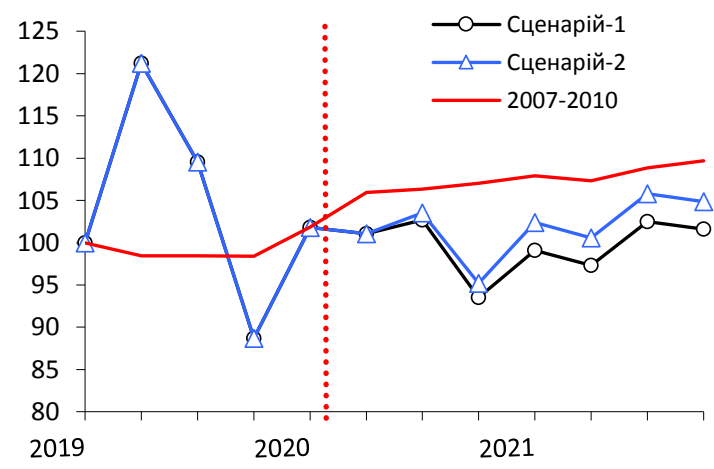

в) аграрне виробництво;

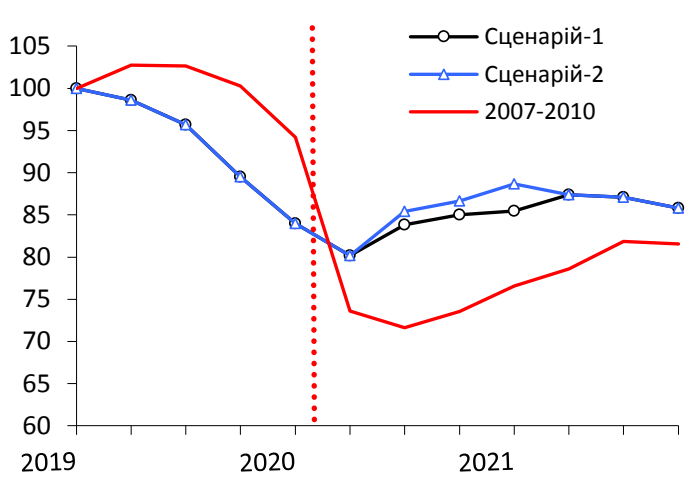

б) промислове виробництво;

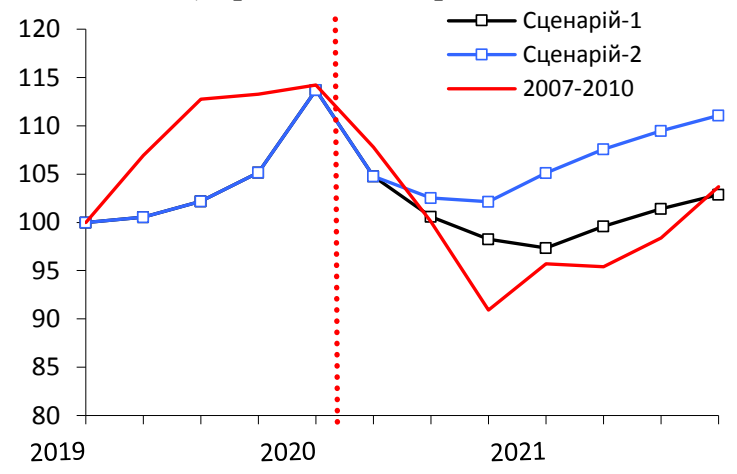

г) роздрібний товарообіг

Рис. 2. Прогнозна траскторія вибраних макроекономічних показників, 2020-2021 pp.

Джерело: розраховано за даними МВФ International Financial Statistics (www.imf.org) та Держкомстату України (www.ukrstat.gov.ua) 
Обсяг роздрібного товарообігу до кінця 2020 р. поступово зменшиться на $14 \%$, але зі середини наступного року відновиться позитивна динаміка. В разі стандартного перебігу карантинних заходів відновлення обсягів роздрібної торгівлі приблизно відповідатиме траєкторії 2009-2010 рр. На кінець 2021 р. обсяги роздрібного товарообігу залишатимуться приблизно на 9\% нижчими від значення на початок 2020 р. В оптимістичному сценарії передкризові обсяги роздрібного товарообігу відновляться до кінця 2021 р. Багато залежить від динаміки обмінного курсу.

Вплив девальвації гривні. 3 погляду триваючих спроб “пом'якшити” монетарну політику НБУ та відновити “реалістичний” обмінний курс гривні, наприклад, таку позицію енергійно пропагує голова Ради НБУ Б. Данилишин [3], становить практичний інтерес дослідження наслідків значної девальвації гривні. Для зручності можна змоделювати наслідки поступового зниження обмінного курсу до 35 грн за долар, як це передбачалося в поміркованопесимістичних сценаріях на початку року [5, с. 2026]. Отримані результати представлено на рис. 3 , де порівнюються прогнози менш оптимістичного перебігу карантинних заходів для обмінного курсу 27-28 грн за долар (сценарій-1) та 27-35 грн за долар (сценарій-1а).

У жодному з випадків не виявлено стимулюючого ефекту від зниження обмінного курсу, що заперечує поширені аргументи на користь “слабкої” гривні. Приміром, стверджується, що зміцнення гривні в 2019 р. було помилковим і призвело до недоотримання кредитних ресурсів, зменшення експорту, доходів бюджету і надходжень у валютні резерви [3; 4] та сповільнення динаміки економічного зростання [1, с. 71-84]. Втім, втрати порівняно незначні для ВВП - трохи більше 1\%. Гірше для промисловості, де втрати від девальвації гривні сягають $11 \%$. Роздрібний товарообіг буде на 3,3\% меншим, що теж немало. Від обмінного курсу не залежить аграрне виробництво, що загалом не дивує, адже сприятлива залежність аграрного експорту від цінового чинника поєднується 3 не менш вагомою оберненою залежністю від імпорту паливно-мастильних матеріалів, техніки, посівного матеріалу, препаратів захисту рослин тощо.

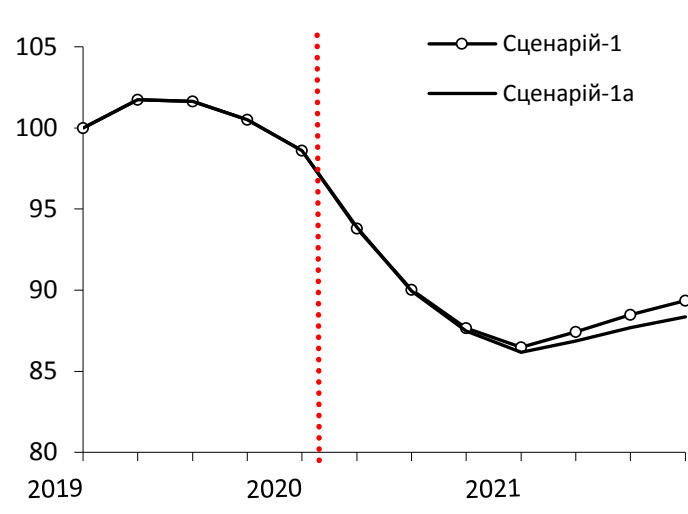

a) ВВП;

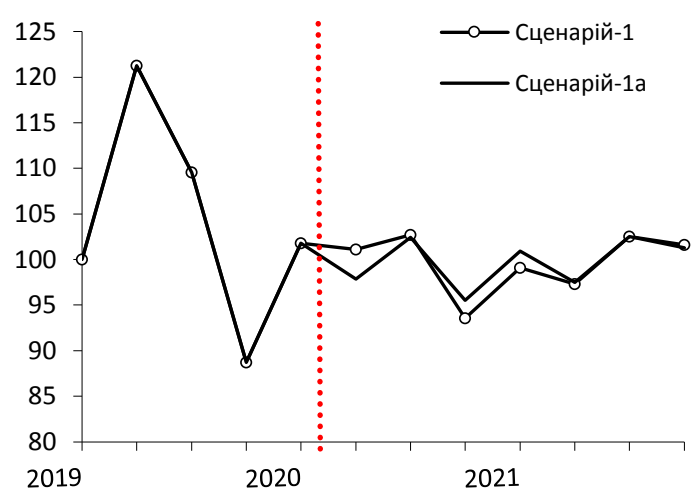

в) аграрне виробництво;

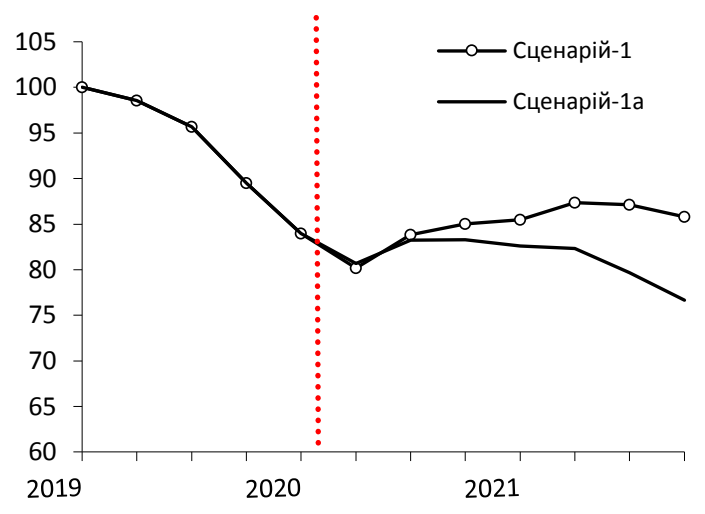

б) промислове виробництво;

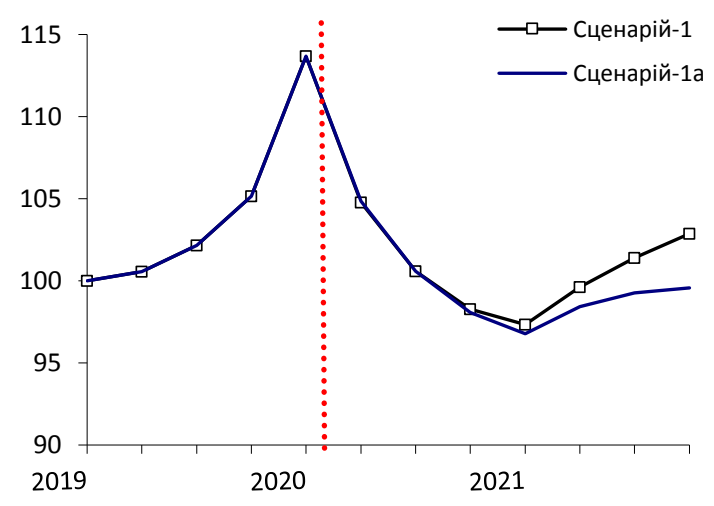

г) роздрібний товарообіг

Рис. 3. Залежність прогнозів вибраних макроекономічних показників від обмінного курсу, 2020-2021 рр.

Джерело: розраховано за даними МВФ International Financial Statistics (www.imf.org) та Держкомстату України (www.ukrstat.gov.ua) 
Отримані результати заперечують доцільність поліпшення цінових співвідношень у зовнішній торгівлі за допомогою знецінення гривні, але це зовсім не означає відсутності переваг від нижчих внутрішніх цін, що дозволяє знизити собівартість виробленої продукції. Відновлення економічного зростання в Україні вагомо залежить від здатності скористатися низькими цінами на енергоносії для зниження коштів виробництва, а відповідно, - здешевлення продукції на внутрішньому і зовнішньому ринках.

Один із найбільших резервів для зниження цін на товари і послуги становить можливе здешевлення бензину внаслідок стрімкого зниження цін на сиру нафту на світових ринках. Нескладні розрахунки показують: поки що ціни на бензин не виявляють ознак такого зниження, що відповідає амплітуді зниження цін на сиру нафту. Якщо прийняти частку сирої нафти у вартості бензину на рівні $60 \%$, а заробітної плати - на рівні $15 \%$, то станом на травень 2020 р. літр бензину А-95 повинен коштувати близько 19-20 грн за літр, тоді як ціна у роздрібній мережі становить не нижче 25 грн за літр. Очевидно, що відсутність належної гнучкості цін у бік зниження становить серйозну перешкоду для відновлення ділової активності після виходу економіки з карантину. 3 іншого боку, непродуктивно намагатися нейтралізувати наслідки надмірно високих внутрішніх цін за допомогою девальвації гривні. Така політика обмінного курсу лише відкладе у часі відновлення докризового рівня ВВП та його компонент.

Висновки і перспективи подальших досліджень у даному напрямі. Отримані прогнози показують, що в 2020- 2021 рр. слід очікувати спад ВВП і промислового виробництва приблизно за кризовим сценарієм 2008-2009 рр. На відміну від двох попередніх криз 2008-2009 і 2014-2015 pp., більш сприятливими видаються зовнішні умови та параметри монетарної політики, що значною мірою нейтралізуватиме наслідки примусової “зупинки” ділової активності. По-перше, здешевлення енергоносіїв спостерігається на тлі стабільних світових цін на аграрну сировину та металопродукцію. Подруге, напередодні нинішніх кризових явищ не спостерігалося загрозливого погіршення сальдо поточного рахунку, яке зазвичай слугувало джерелом панічних очікувань близької девальвації гривні. По-третє, немає відпливу капіталу за кордон, що можна пояснити зміцненням банківської системи та зменшенням зовнішньої заборгованості вітчизняних банків. За квітень-червень ц.р. НБУ відновив докризовий рівень валютних резервів. Також немає відтоку депозитів з банківської системи, що в минулому відразу ж ставало чинником підвищеного попиту на іноземну валюту.

Дуже ймовірно, що стабільність обмінного курсу гривні та низька інфляція дозволять обмежити спад ВВП на позначці 12-13\%. Наступного 2021 р. ВВП може зрости на 1,5-2\%. Багато залежить від збереження не лише цінової і грошової стабільності, але й надходжень від працюючих за кордоном.
Відновленню економіки сприятиме переорієнтація вітчизняного туризму зі зовнішнього на внутрішній. Кризові явища не повинні обмежити обсяги виробництва в аграрному секторі. Якщо карантинні заходи виявляться більш тривалими, обсяг роздрібного товарообігу зменшиться приблизно на $14 \%$. Водночас відмова від будь-яких обмежень вже до кінця поточного року дозволить повернутися на докризовий рівень роздрібного товарообігу в наступному $2021 \mathrm{p}$.

Один із важливих результатів полягає у тому, що девальвація гривні не сприяє відновленню економічного зростання. Це може означати як переважання рестрикційних механізмів у сукупному попиті, так і присутність вагомої оберненої залежності між знеціненням гривні та пропозицією товарів і послуг. Якщо валютні резерви НБУ далі зростатимуть, як це спостерігається у квітні-червні 2020 р., доречно відновити тенденцію до зміцнення обмінного курсу гривні, як це відбувалося в 2018-2019 рр. Зрозуміло, що отримані результати заперечують версію про нібито негативний вплив зміцнення гривні на динаміку ВВП і його компонент в 2019 p.

\section{ЛІТЕРАТУРА}

1. Береславська О. Регулювання валютного курсу як передумова економічного зростання / О. Береславська / Посилення значимості монетарної політики в країнах Центральної і Східної Свропи у посткризовий період і рекомендації для України. - К. : Заповіт, 2019. - С. 71-84.

2. Галасюк В. Економіка України: пандемія Covid-19, нова економічна реальність, рекомендації / В. Галасюк. - К. : Фонд Ганса Зайделя, 2020. $22 \mathrm{c}$.

3. Данилишин Б. Темний бік макроекономічної стабільності / Б. Данилишин // Дзеркало тижня. - 2020. - 18 червня [Електронний ресурс]. - Режим доступу: https://www.dt.ua/finances/temniy-bikmakroekonomichnoyi-stabilnosti-351411_.html.

4. Джус М. Ілюзія стабільності стан грошової сфери в Україні у 2019 році: Аналітичний огляд / М. Джус. - К. : GROWFORD Institute, 2020. - 42 c.

5. Долбнєва Д. Вплив Covid-19 на економіку країн світу / Д. Долбнєва // Проблеми економіки. 2020. - № 1 (43). - С. 20-26.

6. Іванюк У. Аграрний сектор і економічний розвиток України / У. Іванюк, В. Шевчук. - Львів : ПАЇС, 2018. - 431 с.

7. Економічний вплив пандемії Covid-19 на Україну / Д. Заха, В. Мовчан, В. Кравчук, Р. Кірхнер, Г. Полушкін // Аналітичне дослідження № 1/20. - Берлін; Київ: German Economic Team, 2020. $-21 \mathrm{c}$.

8. Кулицький С. Проблеми розвитку економіки України, обумовлені пандемією коронавіруcy Covid-19 у світі, та пошук шляхів їх розв'язання / С. Кулицький // Україна: події, факти, коментарі. - 2020. - № 9. - С. 47-53 [Електронний ресурс]. - 
Режим доступу: http://nbuviap.gov.ua/images/ukraine/ 2020/ukr9.pdf.

9. Програма стимулювання економіки для подолання наслідків Covid-19: “Економічне відновлення": Інформаційно-аналітичні матеріали. - К. : Кабінет Міністрів України, 2020. - 88 с.

10. Чинники і тренди : монографія / [за ред. М. І. Скрипниченко]. - К. : НАН України, ДУ “Ін-т екон. та прогнозув. НАН України", 2018. - 386 с. [Електронний ресурс]. - Режим доступу : http://ief.org.ua/docs/mg/302.pdf.

11. Шавалюк Л. Економіка карантину й після нього / Л. Шавалюк // Тиждень. - 2020. - 26 березня [Електронний ресурс]. - Режим доступу: https://tyzhden.ua/Economics/241939.

12. Шевчук В. Платіжний баланс, економічне зростання і стабілізаційна політика / В. Шевчук. Львів : Кальварія, 2008. - 734 с.

13. Boone, L., Haugh, D., Pain, N., Salins, V. Tackling the fallout from Covid-19 // Economics in the Time of Covid-19 / Baldwin, R., B. Weder di Mauro (eds.). A VoxEU.org Book. - London : CEPR Press, 2020. - P. 37-44.

14. Boissay, F., and Pungcharoenkitkul, P. Macroeconomic effects of Covid-19: an early review // BIS Bulletin No. 7. - Basle : Bank of International Settlements, 2020. -7 p.

15. Brooks, R., Ma, G., Fortun, J. GMV - Covid19 and Global Growth. - Washington : Institute of International Finance, 2020. -2 p.

16. European Economic Forecast. Spring 2020. EU Institutional Paper 125. - Luxembourg : Publications Office of the European Union, 2020. $200 \mathrm{p}$.

17. Global Economic Effects of Covid-19. Washington : Congressional Research Service, 2020. $85 \mathrm{p}$.

18. Maliszewska, M., Mattoo, A. and van der Mensbrugghe, D. The Potential Impact of COVID-19 on GDP and Trade: A Preliminary Assessment / M. Maliszewska, A. Mattoo, D. van der Mensbrugghe // Policy Research Working Paper 9211. - Washington : World Bank, 2020. - 24 p.

19. Mann, C. Real and financial lenses to assess the economic consequences of Covid-19 // Economics in the Time of Covid-19 / Baldwin, R., and B. Weder di Mauro (eds.). A VoxEU.org Book. - London : CEPR Press, 2020. - P. 81-85.

20. McKibbin, W., and Fernando, R. The Economic Impact of Covid-19 // Economics in the Time of Covid-19 / Baldwin, R., and B. Weder di Mauro (eds.). A VoxEU.org Book. - London : CEPR Press, 2020. - P. 45-51.

\section{REFERENCES}

1. Bereslavska, O. (2019), Reguluvannya valutnoho kursu jak peredumova ekonomichnoho zrostannya, Posylennya znachymosti monetarnoji polityky w krajinach Centralnoji i Schidnoji Evropy y посткризовий період і рекомендації для України, Zapovit, Kyiv, pp. 71-84.

2. Galasuk, V. (2020), Ekonomika Ukrainy: pandemia Covid-19, nova ekonomichna realnist, rekomendacii, Hans Zeidel Fund, Kyiv, 22 p.

3. Danylyshyn, B. (2020), Temnyj bik makroekonomichnoji stabilnosti, Dzerkalo Tyzhnya, 18 chervnya, available at: https://www.dt.ua/finances/ temniy-bik-makroekonomichnoyi-stabilnosti-

351411_.html.

4. Dzus, M. (2020), Iluzia stabilnosti stanu hroshovoji sfery v Ukraini v 2019 rotsi: Analitychnyj ohlad, GROWFORD Institute, Kyiv, 42 p.

5. Dolbneva, D. (2020), Vplyv Covid-19 na ekonomiku krajin svitu, Problemy ekonomiky, № 1 (43), pp. 20-26.

6. Ivanyuk, U. and Shevchuk, V. (2018), Agrarnyj sector i ekonomichnyj rozvytok Ukrainy, ПАÏC, Lviv, $431 \mathrm{p}$.

7. Zacha, V., Movchan, V., Kravchuk, V., Kirchner, R. and Polushkin G. (2020), Ekonomichnyj vplyv pandemii Covid-19 na Ukrainu, Analitychne doslidzennya № 1/20, German Economic Team, Berlin, Kyiv, 21 p.

8. Kulytskyj, S. (2020), Problemy rozvytku ekonomiky Ukrainy, obumovleni pandemijeju koronavirusu Covid-19 u sviti, ta poshuk shlachiv ich rozviazannya, Ukraina: podii, fakty, komentari, № 9, pp. 47-53, available at: http://nbuviap.gov.ua/ images/ukraine/ 2020/ukr9.pdf.

9. Programa stymuluwvannya ekonomiky dla podolannya naslidkiv Covid-19: "Ekonomichne vidnovlennya": Informacijno-analitychni materialy (2020), Kabinet Ministriv Ukrainy, Kyiv, 88 p.

10. Chynnyky i trendy (2018), za red. M. I. Skrypnychenko, NAN Ukrainy, DU "Instytut ekonomiky ta prognozuvannya NAN Ukrainy", 386 s., available at: http://ief.org.ua/docs/mg/302.pdf.

11. Shavaluk, L. (2020), Ekonomika karantynu i pisla nyoho, Tyzhden, 26 bereznya, available at: https://tyzhden.ua/Economics/241939.

12. Shevchuk, V. (2008), Platizhnyj balans, ekonomichne zrostannya i stabilizacijna polityka, Kalvaria, Lviv, 734 p.

13. Boone, L., Haugh, D., Pain, N. and Salins, V. (2020), Tackling the fallout from Covid-19, Economics in the Time of Covid-19, Baldwin, R. and B. Weder di Mauro (eds.), A VoxEU.org Book, CEPR Press, London, pp. 37-44.

14. Boissay, F. and Pungcharoenkitkul, P. (2020), Macroeconomic effects of Covid-19: an early review, BIS Bulletin № 7, Bank of International Settlements, Basle, 7 p.

15. Brooks, R., Ma, G. and Fortun, J. (2020), GMV - Covid-19 and Global Growth, Institute of International Finance, Washington, 2 p.

16. European Economic Forecast. Spring 2020 (2020), EU Institutional Paper 125, Publications Office of the European Union, Luxembourg, 200 p.

17. Global Economic Effects of Covid-19 (2020), Congressional Research Service, Washington, 85 p.

18. Maliszewska, M., Mattoo, A. and van der Mensbrugghe, D. (2020), The Potential Impact of 
Вісник Львівського торговельно-економічного університету. Економічні науки. № 59, 2020

COVID-19 on GDP and Trade: A Preliminary Assessment // Policy Research Working Paper 9211, World Bank, Washington, $24 \mathrm{p}$.

19. Mann, C. (2020), Real and financial lenses to assess the economic consequences of Covid-19, Economics in the Time of Covid-19, Baldwin, R. and B. Weder di Mauro (eds.), A VoxEU.org Book, CEPR Press, London, pp. 81-85.
20. McKibbin, W. and Fernando, R. (2020), The Economic Impact of Covid-19, Economics in the Time of Covid-19, Baldwin, R. and B. Weder di Mauro (eds.), A VoxEU.org Book, CEPR Press, London, pp. 45-51.

Стаття надійшла до редакиії 04 березня 2020 року 